\title{
ANALISIS TINGKAT LITERASI SAINS BUKU TEKS BIOLOGI KELAS XI PADA MATERI SISTEM SARAF DI SMA SE- KECAMATAN PANCURBATU TAHUN PEMBELAJARAN 2016/2017
}

\author{
Vijai Eriyandi Ginting ${ }^{*}$, Cicik Suriani \\ Program Studi Pendidikan Biologi,FMIPA Universitas Negeri Medan,Medan \\ Jl. Williem Iskandar Psr. V Medan Estate, Medan, Indonesia, 20221 \\ *E-mail: vijaieriyandi9@gmail.com
}

\begin{abstract}
ABSTRAK
Tujuan penelitian ini dilakukan untuk mendeskripsikan tingkat literasi sains buku teks pelajaran Biologi SMA kelas XI di kecamatan Pancurbatu. Secara khusus penelitian ini menekankan pada dimensi literasi sains meliputi sains sebagai batang tubuh pengetahuan, sains sebagai cara menyelidiki, sains sebagai jalan berpikir, sains sebagai hubungan teknologi dan masyarakat. Penelitian ini dilaksanakan pada 7 Sekolah Menengah Tingkat Atas (SMA) di Kecamatan Pancurbatu yang terdiri dari SMA Negeri 1 Pancurbatu, SMA Swasta YAPIM Sei Glugur, SMA Swasta Methodist Pancurbatu, SMA Swasta Rakyat Sei Glugur, SMA Swasta Era Utama Pancurbatu, SMA Swasta Anastasia dan SMA Swasta Rakyat Pancurbatu. Jumlah sampel yang diteliti adalah 3 buah buku yakni Biologi SMA/MA Kelas XI Pratiwi, Erlangga; Biologi SMA Kelas XI Bagod, Yudhistira dan Biologi SMA Kelas XI Oman, Grafindo Media Pratama. Hasil penelitian menunjukkan bahwa dimensi literasi sains sebagai batang tubuh pengetahuan paling tinggi dan paling dominan dengan rata-rata sebesar $77,20 \%$ dengan kriteria cukup baik, dimensi literasi sains sebagai proses menyelidiki dengan rata-rata sebesar $11,32 \%$ dengan kriteria tidak baik, dimensi literasi sains sebagai cara berpikir dengan rata-rata sebesar 3,39\% dengan kriteria tidak baik, dimensi literasi sains sebagai hubungan teknologi dan masyarakat dengan rata-rata sebesar $8,09 \%$ dengan kriteria tidak baik.
\end{abstract}

Kata Kunci: Literasi Sains, Buku Teks

\section{ABSTRACT}

The purpose of this study was to describe the level of scientific literacy of high school Biology textbook in Pancurbatu sub-district based. Specifically this research emphasizes the dimensions of science literacy including science as a body of knowledge, science as a way of investigating, science as a way of thinking, science as a technological relationship and society. This research was conducted at 7 High School High School in Pancurbatu Subdistrict consisting of SMA Negeri 1 Pancurbatu, Private High School YAPIM Sei Glugur, Private High School Methodist Pancurbatu, Private High School of Sei Glugur, Private High School Era Utama Pancurbatu, Anastasia Private High School and Private High School Pancurbatu People. The number of samples examined were 3 books namely Biology SMA / MA Class XI Pratiwi, Erlangga; High School Biology Class XI Bagod, Yudhistira and High School Biology Class XI Oman, Grafindo Media Pratama. The results showed that the science literacy dimension as the body of knowledge is the highest and most dominant with an average of $\mathbf{7 7 . 2 0 \%}$ with good enough criteria, the science literacy dimension as an investigating process with an average of $11.32 \%$ with the criteria is not good, dimensions of science literacy as a way of thinking with an average of $3.39 \%$ with the criterion is not good, the dimension of science literacy as the relationship of technology and society with an average of $8.09 \%$ with unfavorable criteria.

Keyword: Scientific literacy, textbook

\section{PENDAHULUAN}

Buku teks merupakan komponen pendidikan yang sangat penting dalam proses pembelajaran. Buku teks merupakan media pembelajaran yang dipakai dalam pembelajaran. Tersedianya buku teks yang berkualitas akan mendukung keberhasilan proses pembelajaran. Di Indonesia, buku teks pelajaran merupakan acuan wajib untuk digunakan di satuan pendidikan dasar dan menengah atau perguruan tinggi yang memuat materi pelajaran seperti yang ditulis di dalam Permendiknas No. 11 Tahun 2005. Dalam kegiatan pembelajaran, baik guru maupun siswa tak bisa lepas dari keberadaan buku materi pelajaran.

Kurnia dkk (2014) menyatakan rendahnya kemampuan literasi sains siswa Indonesia ini dipengaruhi oleh banyak hal, antara lain kurikulum 
dan sistem pendidikan, pemilihan metode dan model pengajaran oleh guru, sarana dan fasilitas belajar, sumber belajar, bahan ajar, dan lain sebagainya. Salah satu faktor yang secara langsung bersinggungan dengan kegiatan pembelajaran siswa dan mempengaruhi rendahnya kemampuan literasi sains siswa Indonesia adalah keberadaan sumber belajar siswa, dalam hal ini bahan ajar berbentuk buku, yang selama ini masih merupakan sumber utama pembelajaran siswa disekolah.

Begitu pentingnya keberadaan dan peran buku teks sains terutama buku teks pelajaran Biologi maka perlu dilakukan suatu analisis atau kajian terhadap isi buku teks pelajaran Biologi. Buku teks pelajaran Biologi sebagai bagian dari sains harus menampilkan aspek pembelajaran sains yaitu konsep, proses dan kontak sains juga keterkaitan sains dengan teknologi dan masyarakat dalam isi bukunya. Jika buku teks pelajaran Biologi menerapkan aspek atau hakikat sains maka akan dapat meningkatkan potensi siswa dalam belajar sains dan ketrampilan proses sains siswa. Peningkatan ketrampilan proses sains akan dapat meningkatkan literasi ilmiah siswa. Literasi ilmiah berkaitan dengan bagaimana cara mereka memahami sains dan pengaplikasian berpikir ilmiah dalam kehidupan dan karir mereka.

Udeani (2013) melakukan penelitian terhadap analisis empat tema literasi ilmiah buku teks biologi sekolah menengah pertama di Nigeria dengan menggunakan panduan Procedures for Conducting Content Analysis Of Science Textbooks dari Chiappetta (1991). Hasil penelitian menunjukkan pengarang empat buku teks Biologi tersebut lebih menekankan pada aspek sains sebagai batang tubuh pengetahuan sebagai tema yang paling dominan sebanyak $50-66,7 \%$ dan aspek sains sebagai jalan penyelidikan sebesar 24 $42,9 \%$ dan pengarang buku tidak menekankan sains sebagai proses berpikir yang hanya sebesar 4,6 - $13 \%$ dan hanya sekitar 2,6 - 2,9\% menampilkan teks yang mengaitkan sains, teknologi dan masyarakat pada buku karangannya.

Rumusan masalah dalam penelitian ini yaitu bagaimana tingkat literasi sains buku teks biologi kelas XI SMA se-kecamatan Pancurbatu pada materi sistem saraf berdasarkan keempat dimensi literasi sains,yakni sains sebagai batang tubuh pengetahuan; sains sebagai proses menyelidiki; sains sebagai cara berpikir; sains sebagai hubungan teknologi dan masyarakat?

Penelitian ini bertujuan mendeskripsikan tingkat literasi sains buku teks biologi kelas XI SMA se-kecamatan Pancurbatu pada materi sistem saraf berdasarkan keempat dimensi literasi sains, yakni sains sebagai batang tubuh pengetahuan; sains sebagai proses menyelidiki; sains sebagai cara berpikir; sains sebagai hubungan teknologi dan masyarakat.

\section{METODE PENELITIAN}

Penelitian ini dilaksanakan pada 7 Sekolah Menengah Tingkat Atas (SMA) di Kecamatan Pancurbatu yang terdiri dari SMA Negeri 1 Pancurbatu, SMA Swasta YAPIM Sei Glugur, SMA Swasta Methodist Pancurbatu, SMA Swasta Rakyat Sei Glugur, SMA Swasta Era Utama Pancurbatu, SMA Swasta Anastasia dan SMA Swasta Rakyat Pancurbatu. Waktu penelitian ini dimulai dari bulan April hingga Juni 2017.

Populasi dalam penelitian ini adalah semua buku teks pelajaran biologi SMA kelas XI yang digunakan di enam SMA se kecamatan Pancurbatu. Sampel pada penelitian ini adalah setiap halaman buku teks pada pembahasan materi sistem saraf pada 3 buah buku teks biologi yang dipakai di SMA se-kecamatan Pancurbatu, yakni Biologi SMA/MA Kelas XI Penulis Pratiwi, Penerbit Erlangga; Biologi SMA Kelas XI Penulis Bagod, Penerbit Yudhistira dan Biologi SMA Kelas XI Penulis Oman, Penerbit Grafindo Media Pratama

Jenis penelitian yang digunakan adalah penelitian deskriptif yaitu memaparkan/ mendeskripsikan tingkat literasi sains pada buku teks Biologi. Teknik pengumpulan data yang digunakan adalah analisis dokumentasi pada buku teks Biologi SMA kelas XI. Data yang digunakan dalam penelitian ini adalah data primer. Instrumen yang digunakan dalam penelitian ini adalah berupa lembar observasi. Hasil perhitungan dalam bentuk persentase diintreprestasikan dalam tabel kriteria tingkat literasi sains Rentang persentase tingkat literasi sains buku teks biologi SMA kelas XI menurut Ali (1992) tersaji dalam tabel 1. 
Tabel 1. Rentang persentase tingkat literasi sains buku biologi SMA kelas XI

\begin{tabular}{cc}
\hline Persentase & Tingkat Literasi Sains \\
\hline $90 \%-100 \%$ & Sangat Baik \\
$80 \%-89 \%$ & Baik \\
$70 \%-79 \%$ & Cukup Baik \\
$60 \%-69 \%$ & Kurang Baik \\
$<60 \%$ & Tidak Baik \\
\hline
\end{tabular}

\section{HASIL PENELITIAN}

Hasil penelitian menunjukkan bahwa buku teks yang dianalisis mengandung literasi sains yang memiliki porsi yang tidak seimbang. Adapun 4 dimensi literasi sains yaitu sains sebagai batang tubuh pengetahuan, sains sebagai proses menyelidiki, sains sebagai jalan berpikir, dan sains sebagai hubungan teknologi dan masyarakat. Adapun persentase skor dimensi literasi sains dapat dilihat pada tabel berikut.

Tabel 2. Persentase Skor Dimensi Literasi Sains Untuk Buku Penerbit Erlangga, Yudhistira Dan Grafindo

\begin{tabular}{|c|c|c|c|c|c|c|c|}
\hline \multirow[b]{2}{*}{ Dimensi Literasi Sains } & \multicolumn{2}{|c|}{$\begin{array}{c}\text { Buku I } \\
\text { (Erlangga) }\end{array}$} & \multicolumn{2}{|c|}{$\begin{array}{c}\text { Buku II } \\
\text { (Yudhistira) }\end{array}$} & \multicolumn{3}{|c|}{$\begin{array}{l}\text { Buku III } \\
\text { (Grafindo) }\end{array}$} \\
\hline & $\frac{\sum}{\text { pernyataan }}$ & (\%) & $\frac{\sum}{\text { pernyataan }}$ & (\%) & $\frac{\Sigma}{\text { pernyataan }}$ & (\%) & $\begin{array}{c}\text { Rata-rata } \\
(\%)\end{array}$ \\
\hline $\begin{array}{l}\text { Sains sebagai batang } \\
\text { tubuh pengetahuan }\end{array}$ & 133 & 84,18 & 100 & 68,97 & 131 & 78,44 & 77,20 \\
\hline $\begin{array}{l}\text { Sains sebagai proses } \\
\text { menyelidiki }\end{array}$ & 15 & 9,49 & 19 & 13,10 & 19 & 11,38 & 11,32 \\
\hline $\begin{array}{l}\text { Sains sebagai jalan } \\
\text { berpikir }\end{array}$ & 1 & 0,63 & 6 & 4,14 & 9 & 5,39 & 3,39 \\
\hline $\begin{array}{l}\text { Sains sebagai } \\
\text { hubungan teknologi } \\
\text { dan masyarakat }\end{array}$ & 9 & 5,70 & 20 & 13,79 & 8 & 4,79 & 8,09 \\
\hline Jumlah & 158 & 100 & 145 & 100 & 167 & 100 & 100 \\
\hline
\end{tabular}

Tabel 1 menunjukkan hasil perhitungan analisis dimensi literasi sains buku teks biologi SMA kelas XI dari buku I (penerbit Erlangga), buku II (penerbit Yudhistira) dan buku III (Penerbit Grafindo). Dari hasil penilaian didapatkan persentase dimensi literasi ilmiah yang banyak muncul pada ketiga buku tersebut adalah dimensi sains sebagai batang tubuh pengetahuan (science as a body of knowledge) dan sains sebagai proses menyelidiki (science as a way investigasting).

Semua buku menampilkan dimensi sains sebagai batang tubuh pengetahuan paling tinggi dan paling dominan dengan rata-rata sebesar
$77,20 \%$ pada isi buku daripada ketiga dimensi yang lain. Hal ini menunjukkan penulis cenderung lebih menekankan fakta, konsep, prinsip dan model sains sebagai informasi untuk diketahui siswa. Ketiga buku juga menekankan dimensi sains sebagai proses menyelidiki muncul paling banyak kedua setelah dimensi sains sebagai batang tubuh pengetahuan dengan rata-rata sebesar $11,32 \%$. Dimensi sains sebagai proses menyelidiki menunjukkan bagaimana siswa mengkonstruksi pengetahuan melalui proses sains dan metode ilmiah. Dimensi ini dalam buku lebih banyak disajikan melalui kegiatan eksperimen yang dapat 
dilakukan siswa. Pada ketiga buku juga menekankan menekankan dimensi sains sebagai jalan berpikir dengan rata-rata sebesar 3,39\% yang menggambarkan bagaimana ilmuwan berpikir, melakukan penyelidikan dan menemukan ide yang dapat membantu siswa memahami sains namun proporsinya paling sedikit daripada ketiga dimensi yang lain. Pada ketiga buku juga menekankan dimensi sains sebagai hubungan dengan teknologi dan masyarakat dengan jumlah rata-rata sebesar 8,09\%.'

\section{PEMBAHASAN}

Penelitian yang dilaksanakan di SMA sekecamatan Pancurbatu ini bertujuan mendeskripsikan tingkat literasi sains buku teks biologi berdasarkan keempat dimensi literasi sains, yakni sains sebagai batang tubuh pengetahuan; sains sebagai proses menyelidiki; sains sebagai cara berpikir; sains sebagai hubungan teknologi dan masyarakat.

Secara keseluruhan rata-rata persentase hasil penilaian dimensi literasi pada pada ketiga buku teks biologi yang paling banyak muncul adalah dimensi sains sebagai batang tubuh pengetahuan sebesar $77,20 \%$. Hal ini sesuai dengan penelitian Adisendjaja (2007) yang menganalisis buku ajar biologi kelas $X$ di kota Bandung. Buku ajar yang dianalisis adalah buku ajar yang telah lulus penilaian Pusat Perbukuan dan banyak digunakan di sekolah berdasarkan survey di 4 SMU Negeri kota Bandung. Hasil penelitiannya menunjukakan bahwa tema literasi sains yang paling banyak muncul pada buku teks yang dianalisis yaitu sains sebagai batang tubuh pengetahuan yakni sebesar $82 \%$.

Dimensi sains sebagai batang tubuh pengetahuan menjadi dimensi yang banyak muncul karena dalam penulisan buku teks pelajaran para penulis dan penerbit lebih menekankan pada pengetahuan sains seperti konsep, fakta, prinsip sains sebagai informasi yang harus diketahui dan dipahami siswa dan sedikit dalam peningkatan proses berpikir siswa

Apabila kita melihat fakta di lapangan, para siswa sangat pandai menghafal, tetapi kurang terampil dalam mengaplikasikan pengetahuan yang dimilikinya. Hal ini mungkin terkait dengan kecenderungan menggunakan hafalan sebagai wahana untuk menguasai ilmu pengetahuan, bukan kemampuan berpikir. Tampaknya pendidikan sains di Indonesia lebih menekankan pada abstract conceptualization dan kurang mengembangkan active experimentation, padahal seharusnya keduanya seimbang secara proporsional (Pusbuk, 2003).

Dari ketiga buku tersebut sedikit sekali yang merefleksikan dimensi sains sebagai hubungan teknologi dan masyarakat. Hal ini sesuai dengan penelitian Wahyu dkk (2014) yang menganalisis buku siswa mata pelajaran IPA Kelas VIII berdasarkan literasi sains dimana hasil penelitian yang didapat sebesar $4 \%$ untuk dimensi sains sebagai hubungan teknologi dan masyarakat.. Menurut Campbell (2010) dalam Ariningrum (2013) buku teks yang baik mampu menghubungkan setiap materi dengan penelitian ilmiah serta sains, teknologi, dan masyarakat dengan lebih menonjolkan bagaimana aspek sains diilakukan dan peran sains dalam kehidupan, serta menyebutkan karir-karir yang berhubungan dengan materi sehingga siswa mempunyai pandangan pada karir yang berkaitan.

Dalam BSNP (2006) dikatakan Sains atau IImu Pengetahuan Alam (IPA) berkaitan dengan cara mencari tahu tentang fenomena alam secara sistematis, sehingga IPA bukan hanya penguasaan kumpulan pengetahuan yang berupa fakta-fakta, konsep-konsep, atau prinsip prinsip saja, tetapi juga merupakan suatu proses penemuan. Selanjutnya dikatakan juga bahwa pendidikan sains di harapkan dapat menjadi wahana bagi peserta didik untuk mempelajari diri sendiri dan alam sekitar, serta prospek pengembangan lebih lanjut dalam menerapkannya di kehidupan sehari-hari.

Secara keseluruhan rata-rata persentase hasil penilaian dimensi literasi sains pada ketiga buku teks biolgi yang paling banyak muncul kedua adalah dimensi sains sebagai proses menyelidiki sebesar $11,32 \%$. Hasil ini sesuai dengan penelitian yang dilakukan oleh Ariningrum (2013) yang menganalisis literasi ilmiah buku teks pelajaran biologi SMA di Semarang. Hasil penelitiannya menunjukkan bahwa dimensi literasi sains yang paling banyak kedua yang muncul yaitu dimensi 
sains sebagai proses menyelidiki dengan persentase sebesar $35 \%$.

Secara umum, pada tiga buku yang dianalisis tersebut tidak semua buku melibatkan siswa dalam eksperimen yang diwujudkan dalam Keterampilan Proses Sains. Menurut Wahyu dkk (2014) keterampilan proses sains merupakan keterampilan yang diperlukan untuk menjadi atau bekerja sebagai ilmuwan. Penguasaan pengetahuan dengan keterampilan proses ada kaitan yang erat, konsep dikuasai melalui pengembangan keterampilan proses. Siswa harus membangun sendiri kemampuan berpikir, siswa harus menemukan sendiri dan metransformasikan sendiri informasi kompleks, mengecek sendiri informasi baru dengan aturan-aturannya.

Secara keseluruhan rata-rata persentase hasil penelitian dimensi sains sebagai jalan berpikir merupakan yang paling sedikit muncul dibandingkan dimensi literasi sains lainnya yaitu sebesar 3,39\%. Hasil penelitian ini sesuai dengan penelitian yang dilakukan oleh Adisendjaja (2007) yang menganalisis buku ajar biologi kelas $X$ di kota Bandung yaitu sebesar $8 \%$ untuk sains sebagai jalan berpikir.

Menurut Carin dan Sund (1993) dalam Adisendjaja (2007) sains sebagai pengetahuan yang sistematis atau tersusun secara teratur, berlaku umum, dan berupa kumpulan data hasil observasi dan eksperimen. Aktivitas dalam sains selalu berhubungan dengan percobaan-percobaan yang membutuhkan keterampilan dan kerajinan. Secara sederhana, sains dapat juga didefinisikan sebagai apa yang dilakukan oleh para ahli sains. Dengan demikian, sains bukan hanya kumpulan pengetahuan tentang benda atau makhluk hidup, tetapi menyangkut cara kerja, cara berpikir, dan cara memecahkan masalah. Ilmuwan sains selalu tertarik dan memperhatikan peristiwa alam, selalu ingin mengetahui apa, bagaimana, dan mengapa tentang suatu gejala alam dan hubungan kausalnya.

\section{KESIMPULAN}

Tingkat literasi sains buku teks biologi kelas XI SMA se-kecamatan Pancurbatu pada materi sistem saraf berdasarkan dimensi literasi sains sebagai batang tubuh pengetahuan paling tinggi dan paling dominan dengan rata-rata sebesar 77,20\% dengan kriteria cukup baik, berdasarkan dimensi literasi sains sebagai proses menyelidiki dengan rata-rata sebesar $11,32 \%$ dengan kriteria tidak baik, berdasarkan dimensi literasi sains sebagai cara berpikir dengan rata-rata sebesar 3,39\% dengan kriteria tidak baik, berdasarkan dimensi literasi sains sebagai hubungan teknologi dan masyarakat dengan rata-rata sebesar 8,09\% dengan kriteria tidak baik.

\section{UCAPAN TERIMA KASIH}

Penulis megucapkan terima kasih kepada staf dan para dosen FMIPA Pendidikan Biologi serta guru SMA se-kecamatan Pancurbatu yang telah banyak membantu dan memberikan arahan dalam penyelesaian penelitian saya ini.

\section{DAFTAR PUSTAKA}

Adisendjaja, Y.H., \& Romlah, O.; Analisis Buku Ajar Sains Berdasarkan Literasi Ilmiah Sebagai Dasar Untuk Memilih Buku Ajar Sains (Biologi), Prosiding Mei 2007

Ariningrum, T.R., (2013), Analisis Literasi IImiah Buku Teks Pelajaran Biologi SMA., Skripsi, FMIPA, Universitas Negeri Semarang, Semarang.

Ali, Mohammad, (1992), Penelitian Kependidikan Prosedur Dan Strategi, Angkasa, Bandung.

Kurnia, F., Zulherman, dan Fathurohman, A., (2014), Analisis Bahan Ajar Fisika SMA Kelas XI Di Kecamatan Indralaya Utara Berdasarkan Kategori Literasi Sains, Jurnal Inovasi Dan Pembelajaran Fisika 1(1) :1 - 5

Pratiwi, D.A., Maryati, S., Srikini, Suharno dan Bambang (2012), Biologi Untuk SMA/MA Kelas XI, Erlangga, Jakarta

Udeani, U., (2013), Quatitative Analysis Of Secondary School Biology Textbooks For Scienctific Literacy Themes, Research Journal In Organizational Psychology \& Education Studies 2(1) : 39 - 43.

Wahyu, E., Fathurohman, A, dan Sardianto, (2014), Analisis Buku Siswa Mata Pelajaran IPA Kelas VIII SMP/MTs Berdasarkan Kategori Literasi Sains, Jurnal Inovasi Dan Pembelajaran Fisika 1(1): $\mathbf{1}$ - 5. 